\title{
Multi-component Sex Attractants in Systematic Field Tests of Male Lepidoptera
}

\author{
Tetsu Ando, Hiroshi Kuroko, * Shiro NaKagaki, ** Osamu SaIto, *** \\ Toshio OKU ${ }^{* * *}$ and Nobutaka TAKAHASHI ${ }^{\dagger}$ \\ Department of Agricultural Chemistry, Faculty of Agriculture, \\ The University of Tokyo, Tokyo 113, Japan \\ *Faculty of Agriculture, University of Osaka Prefecture, Sakai 591, Japan \\ **Ibaraki-ken Horticultural Experiment Station, Ami 300-3, Japan \\ ***Tohoku National Agricultural Experiment Station, Morioka 020-01, Japan \\ Received October 1, 1980
}

\begin{abstract}
More than 100 multi-component lures consisting of primary straight chain alkenols, their acetates and alkenals were prepared and tested as attractants of male lepidopterous insects. In field trials, male moths of 52 species were specifically attracted to two- or threecomponent lures. Further 35 lepidopterous species were found to be attracted to single component lures used as control. The main families captured by the multi-component lures were Tortricidae ( 24 species), Noctuidae (11 species) and Acrolepiidae ( 3 species). This successful attraction of so many species indicates the usefulness of systematic field tests using multi-component lures of selected synthetic chemicals.
\end{abstract}

Up to date it is well known that the lepidopterous sex pheromones identified from females are mostly primary straight chain alkenols and their derivatives, acetates and aldehydes. For the discovery of sex attractants for male moths distributed in Japan we have been examining the field attraction tests using the synthetic lures since 1974, and the surveys with single pure compounds, mainly alkenols and their acetates, have indicated the specific attraction of ninety-three species in fifteen families. ${ }^{1)}$ Recently the multi-component nature of the female sex pheromones in Lepidoptera has been claimed, ${ }^{2,3)}$ and some reports of surveys using multi-component candidate lures have been published by Canadian research groups $^{4 \sim 6}$, and preliminary by us. ${ }^{7)}$ This paper deals with the results of the field trials from late in 1976 to early in 1980 on multi-component lures.

\section{MATERIALS AND METHODS}

Alkenols and their acetates were synthesized in our laboratory according to the method described earlier

\footnotetext{
t To whom correspondence should be addressed.
}

using stereo-selective reduction of acetylenic compounds. ${ }^{1)}$ Alkenals were obtained by the treatment of alkenols with pyridinium chlorochromate in methylene chloride. Field tests were also carried out in the same manner described earlier. ${ }^{1)}$ Namely, one mg of each mixed chemicals to be tested was applied to a rubber septum*1 which was placed in a sticky-type trap.*1 A parallel experiment was conducted on each lure and traps were set at a height of $1.5 \mathrm{~m}$ from the ground in a field. Each chemical was renewed every three months. Screening trials were carried out in the following three different environments; (I): a forest in Tokyo (Hachiojishi), ${ }^{* 2}$ (II): a chestnut orchard in Ibaraki-prefecture (Chiyoda-mura) and (III): a forest in Iwate-prefecture (Morioka-shi).

Test A. For the surveys to male moths of the family Noctuidae, ten kinds of two-component mixtures among four monoenyl acetates (Z7-12: OAc, Z7-14: OAc, Z9-14: OAc and Z11-16: OAc)*3 and one dienyl *1 They were kindly supplied by Takeda Chemical Ind.

*2 Asakawa Experiment Forest, Forestry and Forest Products Research Institute.

*3 The chemical formulae are symbolized by $\mathrm{Z}=$ $(Z)$-isomer, $\mathrm{E}=(E)$-isomer, the first number gives the position of unsaturation, the last number gives the carbon atoms in the chain, :OH=alcohol, :OAc= acetate, :Ald =aldehyde. Thus $27-12: O A c=(Z)-7-$ dodecenyl acetate, Z11-14: $\mathrm{Ald}=(Z)$-11-tetradecenal, and so forth. 
acetate $(Z 9, E 12-14: O A c)$ in a ratio of $1: 1$, and four mixtures of these monoenyl acetates $((Z)$-isomers) with their respective geometrical isomers $((E)$-isomers $)$ in a ratio of $1: 1$ were prepared. Attractive activities of these fourteen lures and nine unmixed single lures were tested in the field (I) and (II) from December in 1976 to November in 1977.

Test B. For male moths of the subfamily Tortricinae, two-component lures were prepared by mixing Z11-14: OAc as a common component and another compound as follows, and each mixture was tested in the field (I), (II) and (III) from 1977 to 1978, and the activity of each component was also tested in the same way for comparison. Composition of the nineteen mixtures tested in 1977;7) Z11-14: OAc with E11-14: OAc (in seven different ratios; $9.5: 0.5,9: 1,8: 2,7: 3$, $5: 5,3: 7$ and $1: 9$ ), Z11-14:OAc with $11 \mathrm{Z}-14: \mathrm{OH}$ or Z11-14: Ald (in three different ratios; $9: 1,5: 5$ and 1:9), Z11-14: OAc with Z7-12: OAc, Z7-14: OAc, Z9-14: OAc, 13-14: OAc, Z11-16: OAc or Z9,E12-14: OAc (in one ratio, 1:1). Composition of eighteen mixtures tested in 1978; Z11-14: OAc with E11-14: OAc (in six different ratios; $9: 1,8: 2,7: 3,5: 5,3: 7$ and 1:9), Z11-14: OAc with Z9-12: OAc 11-12: OAc, Z9-14: OAc or Z9,E12-14: OAc (in three different ratios; $1: 9,5: 5$ and $1: 9$ ). Furthermore, twelve lures baited with mixtures of 11-tetradecenal as a common component and another compound were subjected to tests also in the three different fields in 1978. This composition is as follows; Z11-14: Ald with E11-14: Ald, Z11-14:OH or Z9-14: Ald (in three different ratios; 9:1, 5:5 and 1:9), E11-14: Ald with E11-14: OAc (in three different ratios; $9: 1,5: 5$ and $1: 9$ ).

Test $C$. In the field (I) the sixteen kinds of multicomponent lures composed of Z11-16: OH, Z11-16: OAc and Z11-16: Ald were examined for their attractive activities in 1978. These three $C_{10}$ straight chain compounds were mixed in the following ratios to get seven kinds of three-component lures; $1: 1: 1,3: 1: 1$, $1: 3: 1,1: 1: 3,9: 9: 2,9: 2: 9$ and $2: 9: 9$, and twocomponent lures were prepared by possible combinations of two among the three compounds in the following ratios; $9: 1,5: 5$ and $1: 9$. Three unmixed components were also tested in the field.

Test $D$. Three groups of two-component lures (alcohol +acetate, acetate +aldehyde, and aldehyde + alcohol) were made up by combinations of two compounds containing the same mono-unsaturated straight chains but different functionalities. Thus five alkenols, Z5-12: OH, Z7-12: OH, Z8-12: OH, Z9-12: OH and $\mathrm{Z9-14:OH}$, and respective acetates and alkenals were chosen as components. Since two components among them were mixed in three different ratios $(9: 1,5: 5$ and 1:9), fourty-five lures were prepared and they were tested in the field (I) and (II) in 1979. Unmixed single sources, fifteen compounds, were also tested in the same way. Further, activities of the $(E)$-isomers of the alkenals containing the above mono-unsaturated straight chains were examined as single source lures in this test. Two-component lures arising from $\mathrm{C}_{12}$ chain compounds mono-unsaturated at $\mathrm{C}-7$ or $\mathrm{C}-8$ position were tested in the field (III) in 1979.

\section{RESULTS AND DISCUSSION}

\section{Test $A$}

In our early surveys with single sources, it was observed that many species of the family Noctuidae were attracted to the monoene compounds which possessed double bonds at $\mathrm{C}-5$ position from the methyl end of the chains ( $\omega 5$ position). ${ }^{1)}$ Then we conducted field tests of two-component lures (1:1) mainly composed of the $\omega 5$-en acetates. In the trials not only two species of Noctuidae but two of other families were attracted specifically to twocomponent lures as shown in Table I. Further, attraction of three species to single sources was newly confirmed, one of three being a Noctuidae moth. A few number of the moths of these three species were trapped also in earlier experiments.

\section{Test $B$}

Z11-14: OAc has been identified as a common component of sex pheromones in many species of the subfamily Tortricinae. In our earlier surveys, the single source baited with Z11-14: OAc also attracted five species of Tortricinae moths. ${ }^{1)}$ Therefore, two-component lures, in which Z11-14: OAc was mixed with some other unsaturated straight chain compounds, were subjected to field tests. The attracted species are listed in Table II.*4 Z11-14: OAc mixed with its geometrical isomer, E11-14: OAc, interestingly attracted moths of as many as ten species, mainly males of the genera Archippus and Archips, and the suitable ratios of the mixtures were shown in this table. Further it was observed that five chemicals other than Z11-14: OAc and E11-

\footnotetext{
* Detailed data obtained in 1977 are shown in the earlier report. ${ }^{7)}$
} 
Table I. Result of Test A: Sex Attractants Discovered in Field Screening

TESTS FOR NOCTUIDAE MOTHS IN 1977

The field tests were done in two different environments, (I) a forest in Tokyo (Hachioji-shi), (II) a chestnut orchard in Ibaraki-prefecture (Chiyoda-mura).

The chemical formulae are symbolized by $\mathrm{Z}=(Z)$-isomer, $\mathrm{E}=(E)$-isomer, the first number gives the position of unsaturation, the last number gives the carbon atoms in the chain, :OH=alcohol, :OAc= acetate and $:$ Ald $=$ aldehyde.

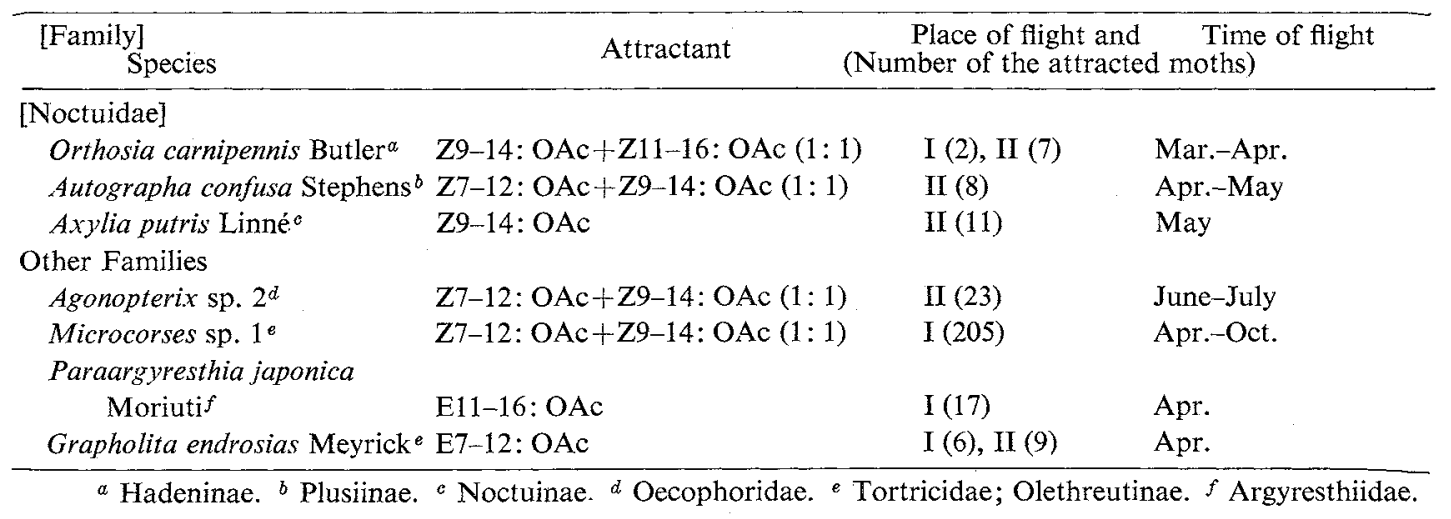

14: OAc played the significant role in the attraction of insects of some other species. Namely Z11-14: OAc mixed with Z11-14: OH, Z1114: Ald, Z9-12: OAc, Z9-14: OAc and Z9, E12-14: OAc attracted three, one, two, one and one species, respectively. Although the former four chemicals were known to be components of sex pheromones in this subfamily, Z9,E1214: OAc has not been identified from Tortricinae females up to date. It must be important to clarify whether this diene acetate is also one component of the sex pheromone in Tortricinae or not. Z11-14: OAc mixed with 1112: OAc, Z7-14: OAc 13-14: OAc or Z11-16: OAc attracted no species specifically in our screening tests.

Above experiments also revealed that the single source baited with Z11-14: Ald attracted two Tortricinae species, confirming that this alkenal is a key compound of Tortricinae sex pheromones. ${ }^{4)}$ We designed the survey to know the attractive activities of the lures baited with Z11-14: Ald or E11-14: Ald as a common component. As shown in Table II, the lures containing the aldehyde attracted six Tortricinae species newly, mainly male moths of the genera Acleris and Croesia.

Subfamilies other than Tortricinae in the family Tortricidae are Olethreutinae, Spargano- thinae and Melanalophinae. It is noteworthy that none of Olethreutinae was attracted in the tests but traps baited with Z11-14: Ald caught the males of one species of Sparganothinae, suggesting that Sparganothinae is more related to Tortricinae than Olethreutinae on chemical nature of the sex pheromone. We have already reported that many species of Olethreutinae and Tortricinae were attracted to the chemicals which were mono-unsaturated at $\omega 4$ and $\omega 3$ positions, respectively. ${ }^{1)}$

In addition to twenty-six Tortricidae species, attraction of fifteen species which belong to eight other families was observed as shown in Table II. This suggests that $\mathrm{C}_{14}$ straight chain compounds mono-unsaturated at $\mathrm{C}-11$ position are very popular components of lepidopterous sex pheromones.

\section{Test $C$}

Z11-16: OAc and Z11-16: Ald were identified as the sex pheromone components in the females of the diamondback moth, Plutella xylostella Linné (Yponomeutoidae: Plutellidae), ${ }^{10)}$ and field trials with synthetic sex pheromones revealed that Z11-16: OH had synergistic effect on the attraction of this male moth. ${ }^{11}$ Recently three-component sex pheromones $^{9,12)}$ and sex attractants ${ }^{6)}$ have been 
Table 11. Result of Test B: Sex Attractants Discovered in Field Screening

TESTS FOR TORTRICINAE MOTH IN 1977 and 1978

The field tests were done in three different environments, (I) a forest in Tokyo (Hachioji-shi), (II) a chestnut orchard in Ibaraki-prefecture (Chiyoda-mura), (III) a forest in Iwate-prefecture (Morioka-shi).

\begin{tabular}{|c|c|c|c|}
\hline $\begin{array}{l}\text { [Family] } \\
\text { Species }\end{array}$ & Attractant & $\begin{array}{l}\text { Place of flight and } \\
\text { ber of the attracted }\end{array}$ & $\begin{array}{l}\text { Time of flight } \\
\text { moths) }\end{array}$ \\
\hline \multicolumn{4}{|l|}{ [Tortricidae; Tortricinae] } \\
\hline Acleris enitescens Meyrick & E11-14: OAc +E11-14: Ald (5: 5) & III (11) & July-Sept. \\
\hline $\begin{array}{l}\text { Acleris filipjevi Obraztsov } \\
\text { Acleris paradiseana }\end{array}$ & E11-14: Ald +E11-14: OAc $(9: 1)$ & $\operatorname{InI}(8)$ & May-Sept. \\
\hline Walsingham ${ }^{a}$ & E11-14: OAc & III (94) & Aug-Sept. \\
\hline Acleris perfundana Kuznetsov & Z11-14: Ald +E11-14: Ald (5:5) & $\begin{array}{l}\text { I (6) } \\
\text { III (10) }\end{array}$ & $\begin{array}{l}\text { Mar-Apr. } \\
\text { May-June }\end{array}$ \\
\hline $\begin{array}{c}\text { Archippus asiaticus } \\
\text { Walsingham }\end{array}$ & E11-14: OAc + Z11-14: OAc $(9: 1)$ & $\begin{array}{l}\text { I ( } 315), \text { II (245) } \\
\text { III (53) }\end{array}$ & $\begin{array}{l}\text { May-Sept. } \\
\text { May-July }\end{array}$ \\
\hline \multicolumn{4}{|l|}{ Archippus breviplicanus } \\
\hline Walsingham ${ }^{a, b}$ & $\mathrm{E} 11-14: \mathrm{OAc}+Z 11-14:$ OAc $(7: 3)$ & III (122) & July-Sept. \\
\hline $\begin{array}{l}\text { Archippus ingentanus } \\
\text { Christoph }^{\alpha}\end{array}$ & 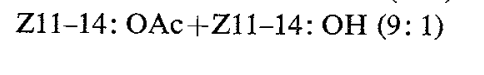 & $\begin{array}{l}\text { II (69) } \\
\text { III }(50)\end{array}$ & $\begin{array}{l}\text { June-July } \\
\text { July }\end{array}$ \\
\hline Archippus peratratus Yasuda & Z11-14: OAc+E11-14: OAc $(9: 1)$ & $\mathbf{I}(65)$ & Apr.-May,Sept.-Oct. \\
\hline $\begin{array}{l}\text { Archippus piceanus similis } \\
\quad \text { Butler }^{\alpha}\end{array}$ & Z11-14: OAc+E11-14: OAc $(8: 2)$ & $\begin{array}{l}\text { I (81), II (97) } \\
\text { III (2) }\end{array}$ & $\begin{array}{l}\text { May-June,Sept.-Oct. } \\
\text { June-July }\end{array}$ \\
\hline $\begin{array}{l}\text { Archips eapsigernus Kennel } \\
\text { Archips fuscocupreanus }\end{array}$ & 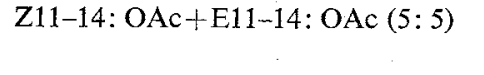 & I (9), II (26) & Jủne, Sept. \\
\hline Walsingham & $\mathrm{Z} 11-14: \mathrm{OAc}+\mathrm{E} 11-14:$ OAc $(8: 2)$ & $\operatorname{III}(26)$ & June-July \\
\hline Archips viola Falkovitsh & E11-14: OAc+Z11-14: OAc $(7: 3)$ & III ( 8$)$ & June--July \\
\hline \multicolumn{3}{|l|}{ Argyrotaenia angustilineata } & June-July \\
\hline Walsingham ${ }^{c}$ & $Z 11-14:$ OAc $+Z 9-12:$ OAc $(5: 5)$ & I (39), II (278) & May-July,Sept.-Oct. \\
\hline $\begin{array}{l}\text { Croesia askoldana Christoph }{ }^{a} \\
\text { Croesia conchyloides }\end{array}$ & \multicolumn{3}{|c|}{ Croesia conchyloides } \\
\hline Walsingham $^{a}$ & Z11-14: Ald & III (52) & June-July \\
\hline Croesia dealbata Yasuda & E11-14: Ald & III (315) & June-Aug. \\
\hline Croesia tigricolor & E11-14: Ald + Z11-14: Ald $(9: 1)$ & $I(66)$ & May-June \\
\hline Walsingham & & III (6) & June-July \\
\hline \multicolumn{4}{|l|}{ Homona magnanima } \\
\hline \multicolumn{4}{|l|}{ Homonopsis foederatana } \\
\hline Kennel $^{a}$ & Z11-14: OAc+E11-14: OAc (5: 5) & I (18), III (7) & May-June \\
\hline \multicolumn{4}{|l|}{ Hoshinoa adumbratana } \\
\hline Walsingham ${ }^{a}$ & Z11-14: Ald & $\operatorname{III}(51)$ & June \\
\hline Pandemis chlorograpta & $\mathrm{Z} 11-14:$ OAc $+\mathrm{E} 11-14:$ OAc $(8: 2)$ & $\mathrm{I}(34)$ & May-June \\
\hline Meyrick $^{a}$ & & III (6) & June-July \\
\hline $\begin{array}{l}\text { Ptycholome lecheana } \\
\quad \text { circumclusana Christoph }{ }^{a}\end{array}$ & $\mathrm{Z} 11-14: \mathrm{OH}+\mathrm{Z} 11-14: \mathrm{OAc}(9: 1)$ & $\begin{array}{l}\text { I ( } 239), \text { II (1), } \\
\text { III (5) }\end{array}$ & May-June \\
\hline $\begin{array}{l}\text { Spatalistis bifasciana } \\
\text { Hübner }{ }^{a}\end{array}$ & Z11-14: OAc +Z9-14: OAc (9:1) & $\begin{array}{l}\text { I }(277) \\
\text { III }(527)\end{array}$ & $\begin{array}{l}\text { June-Oct. } \\
\text { June-Sept. }\end{array}$ \\
\hline $\begin{array}{l}\text { Butler }{ }^{a} \\
\text { Tortricidae; Sparganothinae] }\end{array}$ & Z11-14: OAc & III (50) & June \\
\hline Sparganothis pilleriana & & & \\
\hline $\begin{array}{l}\text { Schiffermüller }{ }^{\alpha} \\
\text { Gracillariidae] }\end{array}$ & Z11-14: Ald & I (1), II (273) & May-June \\
\hline Gracilaria syringella Fabricius & E11-14: Ald +Z11-14: Ald & I (5) & Sept.-Oct. \\
\hline
\end{tabular}


TABLE II. (continued)

\begin{tabular}{|c|c|c|c|}
\hline \multirow{2}{*}{$\frac{\text { [Family] }}{\text { Species }}$} & \multirow[t]{2}{*}{ Attractant } & \multicolumn{2}{|c|}{$\begin{array}{l}\text { Place of flight and Time of flight } \\
\text { ber of the attracted moths) }\end{array}$} \\
\hline & & & \\
\hline Niphonympha anas Stringer & E11-14: OAc +E11-14: Ald $(9: 1)$ & III (75) & June-Aug. \\
\hline \multicolumn{4}{|l|}{ [Yponomeutidae] } \\
\hline \multicolumn{4}{|l|}{ Euhyponomeutoides trachydeltus } \\
\hline Meyrick & Z11-14: OAc & I (10) & Mar.-Apr. \\
\hline Xyrosaris lichneuta Meyrick & $\mathrm{Z} 11-14: \mathrm{OAc}$ & $1(23)$ & Mar.-Apr. \\
\hline \multicolumn{4}{|l|}{ [Argyresthiidae] } \\
\hline \multicolumn{4}{|l|}{ Argyresthia beta } \\
\hline Friese et Moriuti & $\mathrm{Z} 11-14: \mathrm{OH}$ & $\mathrm{I}(41)$ & May-June \\
\hline \multicolumn{4}{|l|}{ [Cosmopterigidae] } \\
\hline Labdia citracma Meyrick & E11-14: Ald & I (14), II (44) & July-Aug. \\
\hline Labdia semicoccinea Stainton & E11-14: Ald & I (9), II (47) & July-Sept. \\
\hline \multicolumn{4}{|c|}{ Stagmatophora niphosticta } \\
\hline Meyrick & E11-14: OAc + Z11-14: OAc $(7: 3)$ & II (227) & July, Sept.-Oct. \\
\hline \multicolumn{4}{|l|}{ [Cochylidae] } \\
\hline Aethes rubigana Treitschke & Z11-14: OAc+E11-14: OAc (5:5) & $\mathrm{I}(9)$ & Sept. \\
\hline \multicolumn{4}{|l|}{ Phtheochroides clandestina } \\
\hline Razowski & Z11-14: OAc +Z9-14: OAc (5: 5) & $I(5)$ & July, Sept. \\
\hline \multicolumn{4}{|l|}{ [Pyralidae] } \\
\hline Pagyda arbiter Butler & Z11-14: Ald +Z11-14: OAc (9: 1) & I (16), II (3) & May-June \\
\hline Paliga minnehaha Pryer & E11-14: OAc & III (26) & May-June \\
\hline Phycitinae sp. 2 & E11-14: Ald & II (74) & Aug.-Oct. \\
\hline \multicolumn{4}{|l|}{ [Noctuidae] } \\
\hline Dadica lineosa Moore ${ }^{e}$ & Z11-14: OAc +Z9-14: OAc $(1: 1)$ & II (16) & May-June \\
\hline Isopolia strigidisca Moore ${ }^{f}$ & Z11-14: OAc & I (9) & Nov.-Dec. \\
\hline \multicolumn{4}{|c|}{ Attraction of these species in 1977 has been reported earlier with detailed data.?) } \\
\hline \multirow{3}{*}{\multicolumn{4}{|c|}{$\begin{array}{l}b \text { The sex pheromone has been reported to be the mixture with E11-14: OAc and Z11-14: OAc }(7: 3) .^{8} \\
{ }^{8} \text { This species was more strongly attracted to the mixture with Z11-14: OAc and Z9-12: OAc than } \\
\text { the mixture with Z11-14: OAc and Z9, E12-14: OAc, the attractant reported earlier. }{ }^{7} \\
{ }^{2} \text { The sex pheromone has been reported to be the mixture with Z11-14: OAc, Z9-12: OAc and 11-12: } \\
\text { OAc }(30: 3: 1)^{8)}\end{array}$}} \\
\hline & & & \\
\hline & & & \\
\hline - Noctuidae; Amphipyrin & $f$ Noctuidae; Cuculliinae. & & \\
\hline
\end{tabular}

reported. In the hope that three-component lures with Z11-16:OH, Z11-16: OAc and Z11-16: Ald might attract the moths taxonomically related to the diamondback moth, field tests of the three-component lures were carried out in addition to two- and one-component lures.

In this experiment sex attractants of four species of the family Acrolepiidae, which is one of the family in the superfamily Yponomeutoidae and closely related to the family Plutellidae, were discovered. Although three of the four species were attracted one- or twocomponent lures, one species, Acrolepiopsis sapporensis Matsumura, was attracted only to three-component lures as shown in Fig. 1. This figure intelligibly shows that these four species may be reproductively isolated one another by their sex pheromones. Further, male moths of the following families were captured in the tests; Argyresthidae (one species), Glyphipterigidae (two species), Pterophoridae (one species) and Noctuidae (four species). The former two families also belong to Yponomeutoidae. Relation between their species and nature of attractants are summarized in Table III. It must be pointed out that two species of Noctuidae were attracted only to the three-component lures, even though total of the captured moths was not so many. 

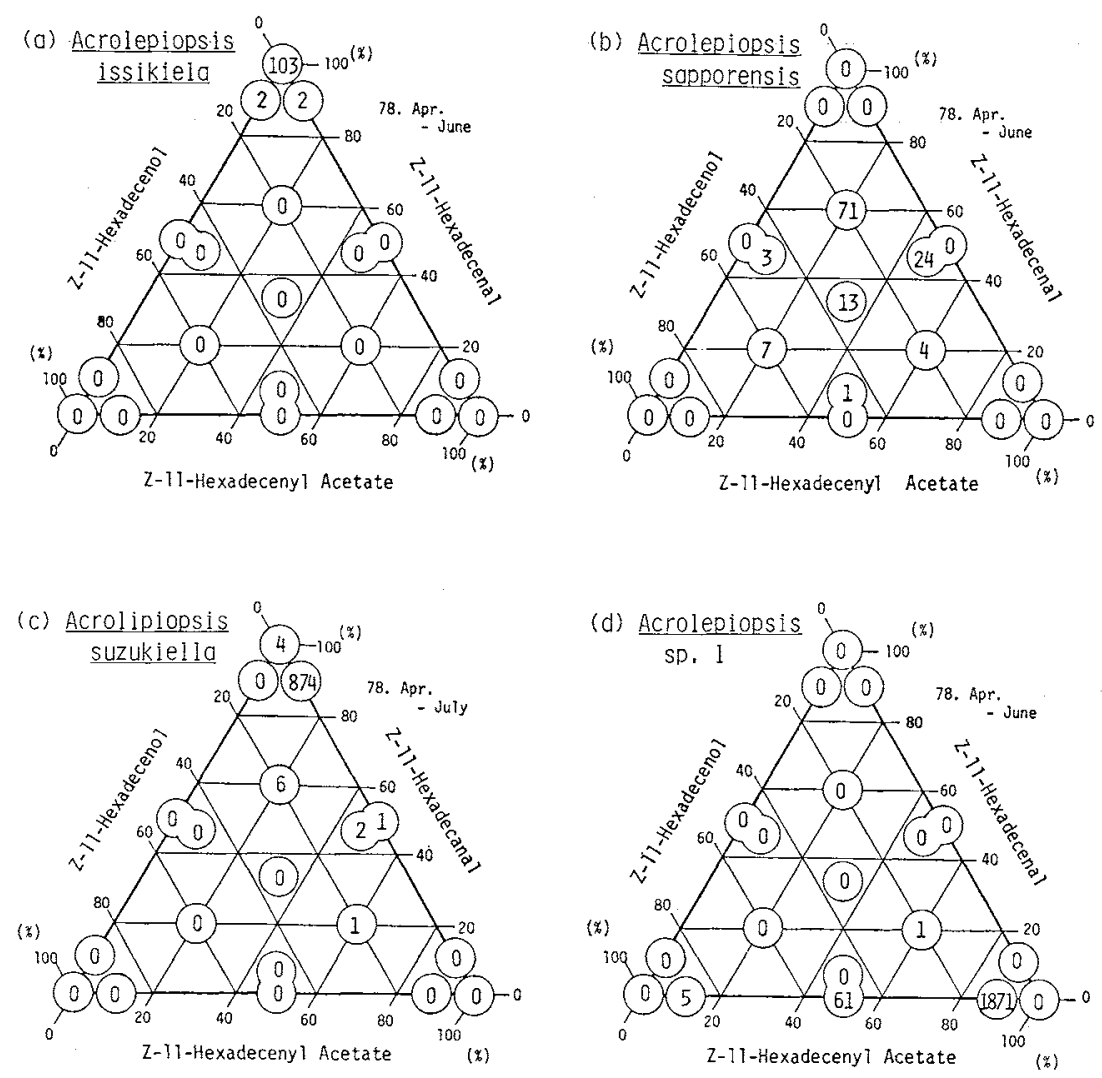

FIG. 1. Field Attractancy of Nineteen Lures for Four Species of the Family Acrolepiidae. Numerals in circles show the total number of the male moths captured by two traps.

\section{Test $D$}

Finally, we surveyed the two-component lures baited the compounds both of which possessed the same mono-unsaturated straight chain but different functional groups as follows, alcohol+acetate, acetate+aldehyde, and aldehyde-alcohol. In the field tests with fourtyfive two-component and fifteen one component lures attraction of ten species to twocomponent lures was revealed, while twelve new species were attracted more strongly to single source lures as shown in Table IV. six of ten species captured by two-component lures were attracted to acetate + aldehyde mixtures, three species to alcohol + acetate mixtures, and one species to a aldehyde +alcohol mixture. It is interesting to note that sex attractants consisting of acetate and aldehyde attracted insects of much more species than other combinations in the random screening tests. And it was observed three species were attracted to an alkenal with $E$-configuration, E11-16: Ald, specifically.

In the field tests conducted in four groups, tests $\mathrm{A} \sim \mathrm{D}$, male moths of fifty-two species were attracted to two- or three-component lures specifically, in addition to the new attraction of thirty-five lepidopterous species to single sources. This satisfactory attraction of many species indicated that the random screening test of multi-component lures may be useful for the sex pheromone study. The chemicals to be mixed should, however, be selected properly on the basis of the knowledge on the multi-component natures of lepidopterous sex pheromones. Two-component sex pheromones identified from female moths up to date can be classified into the following five 
Table III. Result of Test C: Sex Attractants Discovered in Field Screening

Tests for Yponomeutoldae Moths at a Forest in Tokyo (Hachioji-shi) in 1978

\begin{tabular}{|c|c|c|c|}
\hline $\begin{array}{l}\text { [Family] } \\
\text { Species }\end{array}$ & Attractant & $\begin{array}{l}\text { Number of the } \\
\text { attracted moths }\end{array}$ & Time of flight \\
\hline \multicolumn{4}{|l|}{ [Acrolepiidae] } \\
\hline \multicolumn{4}{|l|}{ Acrolepiopsis issikiella } \\
\hline Moriuti & Z11-16: Ald & 103 & Apr.-June \\
\hline Acrolepiopsis sapporensis & Z11-16: Ald +Z11-16: OAc + & & \\
\hline Matsumura & Z11-16: OH $(3: 1: 1)$ & 71 & Apr.-June \\
\hline \multicolumn{4}{|l|}{ Acrolepiopsis suzukiella } \\
\hline Matsumura & Z11-16: Ald +Z11-16: OAc (9:1) & 874 & Apr -July \\
\hline Acrolepiopsis sp. $1^{a}$ & $\mathrm{Z} 11-16: \mathrm{OAc}+\mathrm{Z} 11-16: \mathrm{OH}(9: 1)$ & 1871 & Apr.-June \\
\hline \multicolumn{4}{|l|}{ [Argyresthiidae] } \\
\hline \multicolumn{4}{|l|}{ Argyresthia nemorivaga } \\
\hline Moriuti & Z11-16: Ald & 17 & Apr.-May \\
\hline \multicolumn{4}{|l|}{ [Glyphipterigidae] } \\
\hline \multicolumn{4}{|l|}{ Glyphipterix eulucotoma } \\
\hline Diakonoff et Arita & Z11-16: OAc $+211-16:$ Ald $(5: 5)$ & 41 & June-July \\
\hline \multicolumn{4}{|l|}{ Glyphipterix nigromarginta } \\
\hline Issiki & Z11-16: OAc +Z11-16: Ald (5:5) & 65 & May-June \\
\hline \multicolumn{4}{|l|}{ Other Families } \\
\hline Matsumura $^{b}$ & Z11-16: OAc $+Z 11-16:$ Ald $(9: 1)$ & 7 & Apr.-May \\
\hline Orthosia lizetta Butler ${ }^{o}$ & Z11-16: OAc +Z11-16: Ald (5:5) & 7 & Mar.-Apr. \\
\hline Orthosia munda & Z11-16: OH+Z11-16: Ald + & & \\
\hline Schiffermüller ${ }^{e}$ & Z11-16: OAc $(9: 9: 2)$ & 7 & Mar.-Apr. \\
\hline Eupsilia tripunctata Butler ${ }^{d}$ & $\begin{array}{l}\text { Z11-16: OAc +Z11-16:Ald + } \\
\quad \text { Z11-16: OH }(9: 9: 2)\end{array}$ & 5 & Mar. \\
\hline Telorta acuminata Butler ${ }^{d}$ & Z11-16: Ald & 5 & Nov.-Dec. \\
\hline $\begin{array}{l}\text { This species was more } \\
\text { OAc, tested earlier. }{ }^{1)}\end{array}$ & ongly attracted to the two-comp & lure than the & le source, $\mathrm{Z11-1}$ \\
\hline
\end{tabular}

groups; 1) mixture of geometrical isomers, e.g. Z12-14: OAc+E12-14: OAc (oriental corn borer, Ostrinia furnacalis Guenée), ${ }^{13)}$ 2) mixture of double bond positional isomers, e.g. Z5-10: OAc +Z7-10: OAc (common cutworm moth, Agrotis fucosa Butler), ${ }^{14}$ 3) mixture of hydrogenated derivatives, e.g. E4,Z7-13: OAc +E4,Z7,Z10-13: OAc (potato tuberworm moth, Phthorimaea operculella Zeller), ${ }^{15}$ 4) mixture of the compounds with same carbon chain but different functional groups, e.g. Z11-16: OAc + Z11-16: Ald (diamondback moth, Plutella xylostella Linné), ${ }^{10}$ and 5) mixture of the compounds which possess the different chain length by two carbons, e.g. Z1116: Ald+Z13-18: Ald (rice stem borer, Chilo suppressalis Walker). ${ }^{16,17)}$ Two-component sex pheromones whose component are different in the points more than two chemical character- istics has not been known, e.g. Z12-14: OAc+ E11-14: OAc, Z5-10: OAc+Z7-10: Ald, E4, Z7-13: OAc $+E 4, Z 7, Z 10-14:$ OAc, and so on. We prepared one hundred and eighteen multicomponent lures according to the above information. Particularly, as mentioned in the test B, Z11-14: OAc was chosen for a common component to mix with eleven different chemicals, and new sex attractants for eighteen Tortricinae species were successfully discovered. It may be recommended to determine one chemical as a common component and then mix this chemical with the compounds having the chemical nature described as 1) 5).

The identifications of alkenals as components of some pheromones and discoveries of new attractants by screening tests with synthetic alkenals ${ }^{18}$ have indicated that alkenals are one of significant groups of lepidopterous sex 
Table IV. Result of Test D: Sex Attractants Discovered in Field Screening Tests in 1979

The field tests were done in three different environments, (I) a forest in Tokyo (Hachioji-shi), (II) a chestnut orchard in Ibaraki-prefecture (Chiyoda-mura), (UI) a forest in Iwate-prefecture (Morioka-shi).

\begin{tabular}{|c|c|c|c|}
\hline $\begin{array}{l}\text { [Family] } \\
\text { Species }\end{array}$ & \multicolumn{3}{|c|}{$\begin{array}{l}\text { Place of flight and Time of flight } \\
\text { (Number of the attracted moths) }\end{array}$} \\
\hline \multicolumn{4}{|l|}{ [Gracillariidae] } \\
\hline \multicolumn{3}{|l|}{ Caloptilia theivora } & Apr.-May,June-Aug. \\
\hline \multicolumn{4}{|l|}{ [Yponomeutidae] } \\
\hline \\
\hline \multicolumn{3}{|l|}{ Argyresthia chamaecypariae } & May-June \\
\hline \multicolumn{4}{|l|}{ [Gelechiidae] } \\
\hline Meyrick & E7-12: OAC & III (246) & June-Aug. \\
\hline \multicolumn{4}{|l|}{ [Xyloryctidae] } \\
\hline 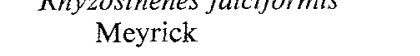 & Z7-12: OAc $+Z 7-12:$ Aid $(9: 1)$ & III $(90)$ & July-Aug. \\
\hline \multicolumn{4}{|l|}{ [Oecophoridae] } \\
\hline Agonopterix encentra Meyrick & $\mathrm{Z} 7-12: \mathrm{OH}+\mathrm{Z} 7-12: \mathrm{OAc}(9: 1)$ & III (45) & Sept.-Nov. \\
\hline Gen. et sp. 1 & Z7-12: OAc + Z7-12: Ald (9: 1) & III (65) & June-July \\
\hline \multicolumn{4}{|l|}{ [Tortricidae; Olethreutinae] } \\
\hline Epinotia leucantha Meyrick & $\mathrm{Z9}-12: \mathrm{OH}$ & II (6) & Aug.-Sept. \\
\hline Grapholita sp. 1 & Z8-12: OAc & III (10) & May-June \\
\hline \multicolumn{4}{|l|}{ Matsumuraeses ussuriensis } \\
\hline \multicolumn{4}{|l|}{ Olethreutes humeralis } \\
\hline Walsingham & $\mathrm{Z} 8-12: \mathrm{OH}+\mathrm{Z} 8-12: \mathrm{OAc}(5: 5)$ & III (11) & June-July \\
\hline \multicolumn{4}{|l|}{ [Tortricidae; Tortricinae] } \\
\hline $\begin{array}{c}\text { Kawabea ignavana } \\
\text { Christoph }\end{array}$ & Z7-12: OAC & $\begin{array}{l}\text { I (6) } \\
\text { III }(38)\end{array}$ & $\begin{array}{l}\text { Nov.-Dec. } \\
\text { Sept.-Nov. }\end{array}$ \\
\hline \multicolumn{4}{|l|}{ [Pyralidae] } \\
\hline Bradina sp. 1 & E11-16: Ald & $I(8)$ & July-Aug. \\
\hline \multicolumn{4}{|l|}{ [Pterophoridae] } \\
\hline \multicolumn{4}{|l|}{ Pterophorus jezonicus } \\
\hline Matsumura & Z9-12: Ald & II (6) & Sept. \\
\hline Trichoptilus wahlbergi Zeller & Z7-12: Ald +Z7-12: OH $(9: 1)$ & I (11), II (5) & May-July, Oct. \\
\hline [Limacodidae] & & & \\
\hline Microleon longipalpis Butler & Z7-12: Ald & $1(4)$, II $(10)$ & May-July \\
\hline [Thyatiridae] & & & \\
\hline $\begin{array}{l}\text { Epipsestis peromata Inoue } \\
\text { [Noctuidae] }\end{array}$ & Z9-14: Ald & I (12) & Oct.-Nov. \\
\hline $\begin{array}{l}\text { Hermonassa cecilia } \text { Butler }{ }^{a, e} \\
\text { Sineugraphe disgnosta }\end{array}$ & Z9-14: OAc + Z9-14: Ald $(9: 1)$ & II (14) & Oct.-Nov. \\
\hline Boursin ${ }^{a}$ & $27-12: \mathrm{OH}$ & I (2), III (13) & Sept.-Oct. \\
\hline Orthosia evanida Butler ${ }^{b}$ & Z9-14: Ald & $\begin{array}{l}\text { I }(58) \\
\text { III (6) }\end{array}$ & $\begin{array}{l}\text { Jan.-Mar. } \\
\text { May }\end{array}$ \\
\hline $\begin{array}{l}\text { Orthosia gothica askoldensis } \\
\text { Staudinger } \\
\text { Sta }\end{array}$ & Z9-14: Ald +Z9-14: OAc $(9: 1)$ & $\begin{array}{l}\text { I (2) } \\
\text { III (4) }\end{array}$ & $\begin{array}{l}\text { Mar. } \\
\text { May }\end{array}$ \\
\hline Orthosia limbata Butler ${ }^{b}$ & Z9-14: OAc +Z9-14: Ald $(9: 1)$ & I (95) & Jan.-Mar. \\
\hline Blepharosis costalis Butler ${ }^{b}$ & Z9-14: Ald + Z9-14: OAc $(9: 1)$ & $I(14)$ & Oct.-Dec. \\
\hline Rhynchaglaea fuscipennis Sugi & $c, f$ Z9-14: Ald & I $(80)$ & Nov.-Mar. \\
\hline Autographa jessica Butler ${ }^{d}$ & $\mathrm{Z} 7-12: \mathrm{OAc}+\mathrm{Z} 7-12: \mathrm{OH}(9: 1)$ & II (5) & May, Nov. \\
\hline
\end{tabular}

$a$ Noctuinae. $b$ Hadeninae. ${ }^{c}$ Cucullinae. $d$ Plusinae.

$e$ This species was more strongly attracted to the mixture with Z9-14: OAc and Z9-14: Ald than the single source, Z9-14: OAc, tested earlier.')

$f$ This species was more strongly attracted to the alkenal, Z9-14: Ald, than the acetate, Z7-12: OAc, tested earlier. ${ }^{1)}$ 
pheromones. In our field tests (tests B, C and D) lures baited with a aldehyde(s) only and aldehyde + acetate caught male moths of twenty-one and sixteen species, respectively, supporting this idea. These number are not too few in comparison with the results with alkenols and their acetates. Although the insects in families Plutellidae, Argyresthiidae, Glyphipterigidae, Xyloryctidae, Limacodidae and Thyatiridae have not been attracted in our earlier surveys, ${ }^{12}$ in this investigation males of some species of the above families were shown to be attracted by the lures containing alkenals. Lepidopterous species attracted in our field screening tests since 1974 in total are no less than one hundred and seventy, which belong to twenty-one families. Consequently it is concluded that unsaturated primary alcohols with straight chain and their derivatives, acetates and aldehydes, constitute a main group of female sex pheromones of Lepidoptera being native in Japan.

\section{REFERENCES}

1) T. Ando, S. Yoshida, S. Tatsuki and N. Takahashi, Agric. Biol. Chem., 41, 1485 (1977).

2) W.L. Roelofs and R.T. Cardé, Ann. Rev. Entomol., 22, 377 (1977).

3) Y. Tamaki, "Chemical Control of Insect Behavior: Theory and Application," ed. by H. H. Shorey and J. J. McKelvey, Jr., John Wiley \&
Sons Inc., N. Y., 1977, pp. 253-285.

4) J. Weatherston, J. E. Percy and L. M. MacDonald, Experientia, 32, 178 (1976).

5) W. Steck, E.W. Underhill, M.D. Chisholm, B.K. Bailey, J. Loeffler and C. G. Devlin, Can. Entomol., 109, 157 (1977).

6) W. F. Steck, M. D. Chisholm, B. K. Bailey and E. W. Underhill, Can. Entomol., 111, 1263 (1979).

7) T. Ando, H. Kuroko, S. Nakagaki, O. Saito, T. Oku and N. Takahashi, Agric. Biol. Chem., 42, 1081 (1978).

8) H. Sugie, K. Yaginuma and Y. Tamaki, Appl. Entomol. Zool., 12, 69 (1977).

9) H. Noguchi, Y. Tamaki and T. Yushima, Appl. Entomol. Zool., 14, 225 (1979).

10) Y. Tamaki, K. Kawasaki, H. Yamada, T. Koshihara, N. Osaki, T. Ando, S. Yoshida and H. Kakinohata, Appl. Entomol. Zool., 12, 208 (1977).

11) T. Ando, T. Koshihara, H. Yamada, M. H. Vu, N. Takahashi and Y. Tamaki, Appl. Entomol. Zool., 14, 362 (1979).

12) T. Ando, K. Kishino, S. Tatsuki and N. Takahashi, Agric. Biol. Chem., 44, 765 (1980).

13) T. Ando, O. Saito, K. Arai and N. Takahashi, Agric. Biol. Chem., 44, 2643 (1980).

14) S. Wakamura, Appl. Ent. Zool., 13, 290 (1978).

15) C. J. Persoons, S. Voerman, P. E. J. Verwiel, F. J. Ritter, W. J. Nooyen and A. K. Minks, Ent. Exp. \& Appl., 20, 289 (1976).

16) B. F. Nesbitt, P. S. Beevor, D. R. Hall, R. Lester and V. A. Dyck, J. Insect Physiol., 21, 1883 (1975).

17) K. Ohta, S. Tatsuki, K. Uchiumi, M. Kurihara and J. Fukami, Agric. Biol. Chem., 40, 1897 (1976).

18) E. W. Underhill, M. D. Chisholm and W. Steck, Environ. Entomol., 6, 333 (1977). 